\title{
The histological slides and drawings of Cajal
}

\author{
Pablo Garcia-Lopez ${ }^{1,2+}$, Virginia Garcia-Marin ${ }^{1,3 *+}$ and Miguel Freire ${ }^{1}$ \\ 1 Instituto Cajal, Consejo Superior de Investigaciones Científicas, Madrid, Spain \\ 2 School of Visual of Arts, New York, NY, USA \\ ${ }^{3}$ Laboratorio de Circuitos Corticales, Centro de Tecnología Biomédica, Universidad Politécnica de Madrid, Madrid, Spain
}

\section{Edited by:}

Laurence J. Garey, International Brain Research Organization, Switzerland

\section{Reviewed by:}

Guy Elston, International Brain

Research Organization, Switzerland

Laurence J. Garey, International Brain

Research Organization, Switzerland

\section{${ }^{*}$ Correspondence:}

Virginia Garcia-Marin, Laboratorio de

Circuitos Corticales, Centro de

Tecnología Biomédica, Universidad

Politécnica de Madrid, Campus

Montegancedo S/N, Pozuelo de

Alarcón, 28223 Madrid, Spain;

Instituto Cajal, Consejo Superior de

Investigaciones Científicas, Avenida

Doctor Arce 37, 28002 Madrid, Spain.

e-mail:vgmarin@cajal.csic.es

${ }^{\dagger}$ Pablo Garcia-Lopez and Virginia

Garcia-Marin contributed equally to this

work.
Ramon y Cajal's studies in the field of neuroscience provoked a radical change in the course of its history. For this reason he is considered as the father of modern neuroscience. Some of his original preparations are housed at the Cajal Museum (Cajal Institute, CSIC, Madrid, Spain). In this article, we catalogue and analyse more than 4,500 of Cajal's histological preparations, the same preparations he used during his scientific career. Furthermore, we catalogued Cajal's original correspondence, both manuscripts and personal letters, drawings and plates. This is the first time anyone has compiled an account of Cajal's enormous scientific production, offering some curious insights into his work and his legacy.

Keywords: Cajal, histological preparations, drawings

\section{INTRODUCTION}

Santiago Ramon y Cajal is considered the father of modern neuroscience (DeFelipe, 2002a) for his outstanding studies of the microanatomy his observations regarding degeneration and regeneration, and his theories about the function, development and plasticity of virtually the whole central nervous system (CNS). Some of his original possessions are housed at the Cajal Museum (Cajal Institute, CSIC, Madrid, Spain). The Museum preserves the items that Cajal bequeathed to the Institute in 1931:

“... my collection of microscopic slides, cupboards to keep them in and some scientific devices of my property, such as the microtome and two microscopes, a Zeiss model and another Leitz model, and finally, a Zeiss microphotographic device"1.

The Museum also holds other items that Cajal's family has entrusted to it having been established in homage to his memory. Although a detailed inventory of the Museum's contents is not yet available, we estimate that it houses a total of 30,218 items of a widely varied nature. These items have been divided into 26 groups for cataloguing and to facilitate their study: 1 . Photographic archive $(2,384)$; 2. Precision balances (2); 3. Photographic cameras (5); 4. Correspondence $(2,584) ; 5$. Ceramics (2); 6. Colorants, Reagents

\footnotetext{
1“...mi colección de preparaciones microscópicas, armarios para guardarlas y algunos instrumentos científicos de mi propiedad, tales como un micrótomo y dos microscopios, uno modelo Zeiss y otro modelo Leitz, y en fin, un aparato microfotográfico Zeiss".
}

and Solutions (387); 7. Notebooks (11); 8. Scientific drawings ${ }^{2}$ (1.976); 9. Artistic drawings (2); 10. Diplomas and Certificates (109); 11. Sculptures (6); 12. Phonographs (1); 13 Books, Newspapers and Journals $(7,000) ; 14$. Handwritten manuscripts $(1,952) ; 15$. Gas lighters (3); 16. Medals, Decorations and Awards (25); 17. Optic microscopes (21), Boxes (5) and Microphotography devices (1); 18. Microtomes (3); 19. Furniture (20); 20.Straight razors (9);21.Personal objects (15); 22. Paintings (10); 23. Histological $\operatorname{slides}^{3}(13,676) ; 24$. Projectors (4); 25. Telescope (1); 26. Textiles (4: Figure 1).

Cataloguing ${ }^{4}$ the histological slides and drawings was achieved using the Museum's systematic documentation catalogue, generating a list of the histological slides and scientific drawings as a Microsoft Access database. Each entry contains an image field and different text fields to describe it. In this article, we will present an analysis of Cajal's effects that he used in his research, which could help to comprehend his enormous scientific production. The catalogue offers some curious insights into his work and his legacy. Furthermore, we present some of Cajal's scientific drawings with his histological slides.

\footnotetext{
${ }^{2}$ Including those scientific drawings belonging to Cajal $(1,907)$ and those belonging to his disciples: Tello (37), J. Ramón Fañanás (5), Domingo Sánchez, etc.

${ }^{3}$ Including those histological slides belonging to Cajal $(4,529)$ and those belonging to his disciples $(9,147)$ : Domingo Sanchez, J. Francisco Tello, etc.

${ }^{4}$ Before starting to catalogue slides and scientific drawings, they were moved from the original cupboards to preservation cabinets where they could be more adequately stored in conservation conditions. Most of the restoration has been carried out by a qualified team directed by Pilar Sedano (Sedano Espín et al., 2003).
} 

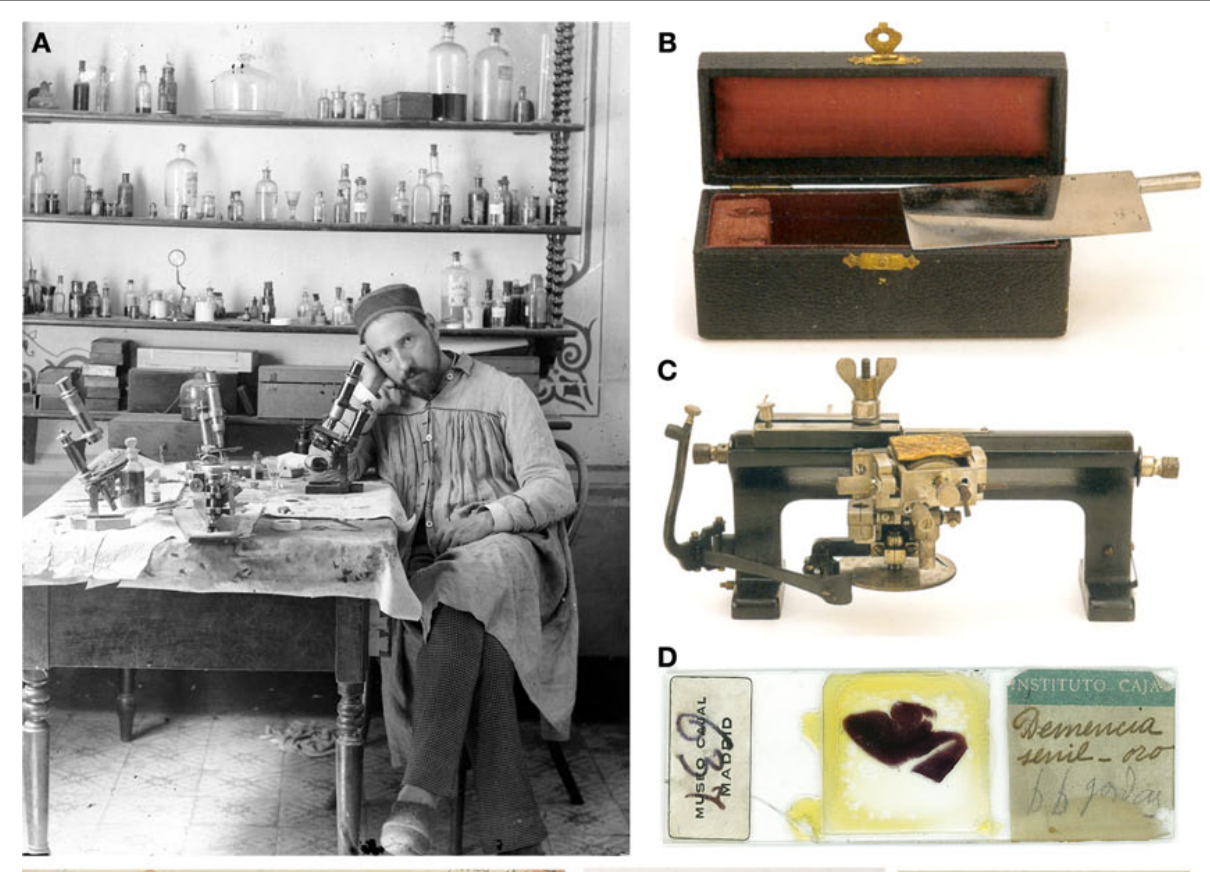

。

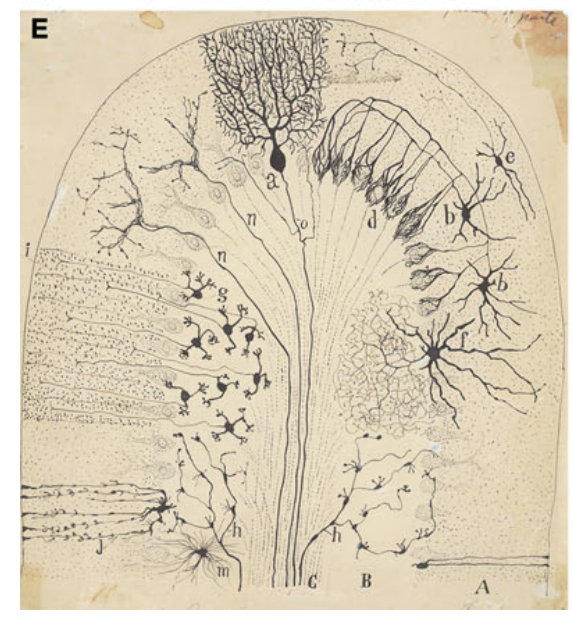

$\mathbf{F}$
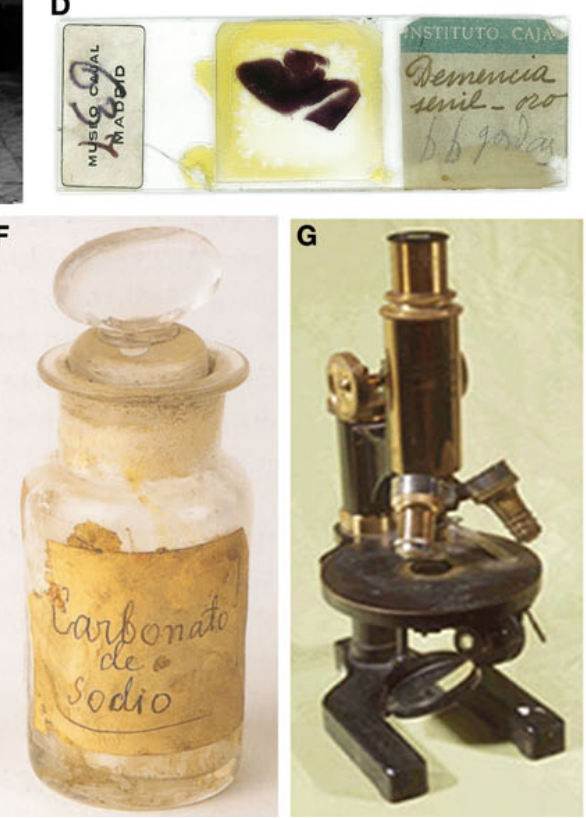

FIGURE 1 | Examples of some of the items held at the Cajal Museum. (A) Photographic archive; (B) Microtome knife; (C) Microtome; (D) Histological slide; (E) Scientific drawing; (F) Reagent; (G) Microscope; (A,B,E: reproduced with the permission of the Inheritors of Santiago Ramón y Cajal @).

\section{GENERAL DATA OBTAINED BY CATALOGUING THE HISTOLOGICAL SLIDES}

Cataloguing the material was a useful means to identify the histological preparations, and determine when Cajal prepared them, to classify them into different groups according to the biological discipline, and to define the method of staining and the species studied.

\section{CLASSIFICATION OF THE HISTOLOGICAL PREPARATIONS ACCORDING TO AUTHOR AND DATE}

The majority of the 4,529 histological preparations were made personally by Cajal. Seventy two preparations housed in the Cajal collection belonged to other scientists, who exchanged preparations with Cajal or who sent him preparations to study. Among these, there are preparations from Cajal's disciples [Claudio Sala (9), Lorente de No (3), Francisco Tello (3), Durán Ventosa (2)] or from other scientists, such as Dr. Sigmund (30), M. Heidenhain (7), Luis Simarro (7) or López García (2).
Regarding the dating, it was very rare to find histological preparations with the exact date they were made, although there were some examples where the date was clearly written by Cajal on the slide (Figure 2M). Different options have been taken into account in order to date the preparations, such as: the handwritten or typewritten labels stuck on the preparations (Figure 2), the type of labels, the publication of articles related to the preparation, the method employed in each slide, and even Cajal's biography.

There is wide variability in the labels attached to Cajal's slides. In some cases, the name of a city is recorded (Zaragoza, Valencia, Barcelona and Madrid) according to where Cajal lived at the time. For this reason, we can approximate the date of the histological preparations to these periods. Thus, when Zaragoza is written on a histological slide, it could date from 1877 to 1884 (Figure 2A), whereas Valencia could indicate that the slide was made between 1884 and 1897 (Figure 2B). Likewise, histological slides labeled Barcelona could have been made from 1887 to 1892 (Figure 2C). 

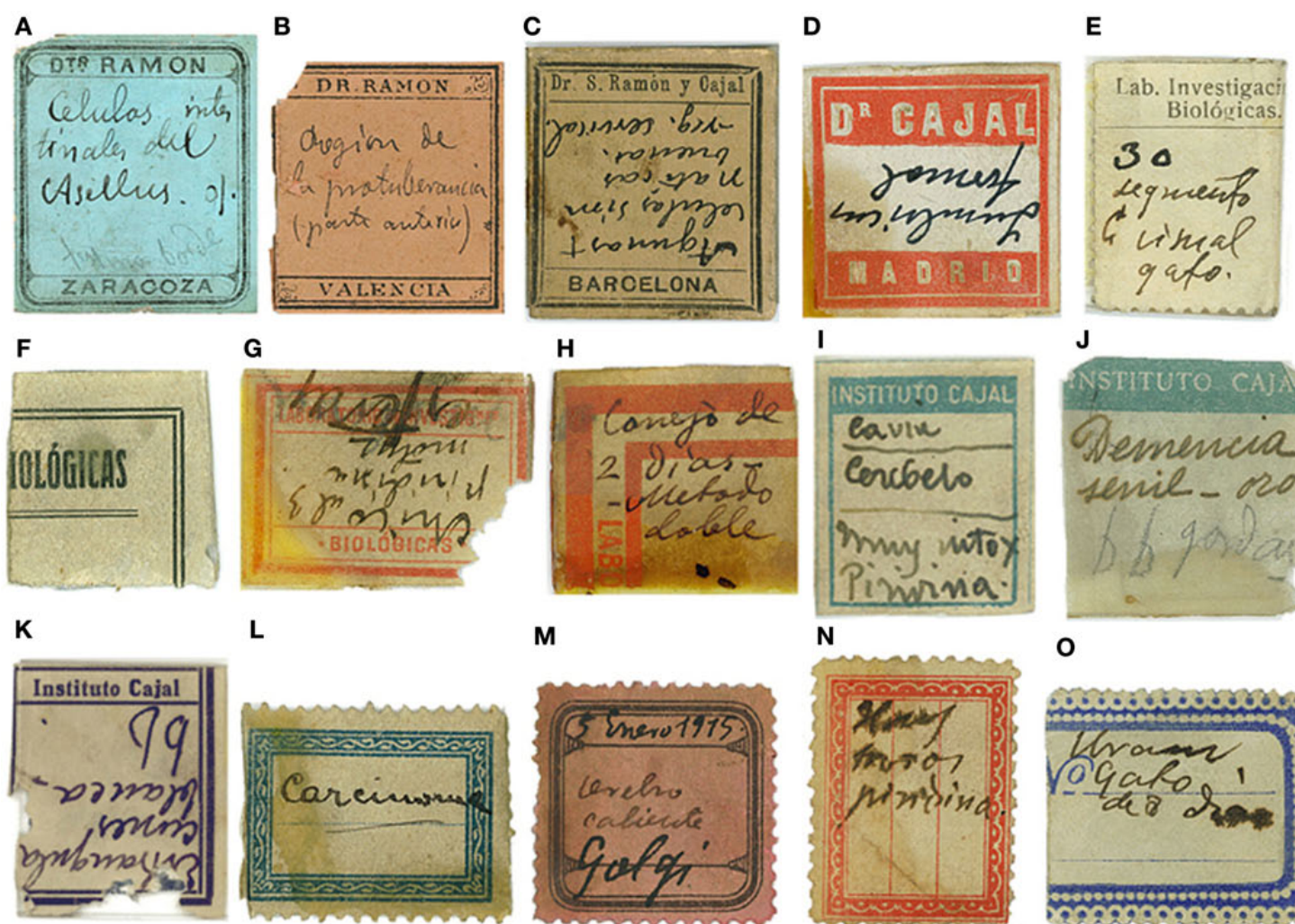

L

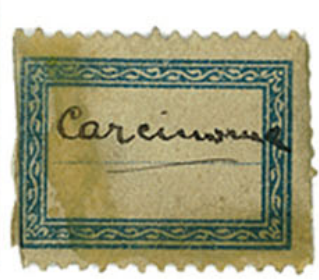

$\mathbf{M}$

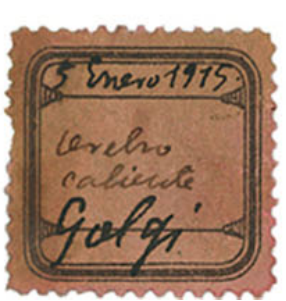

$\mathbf{N}$

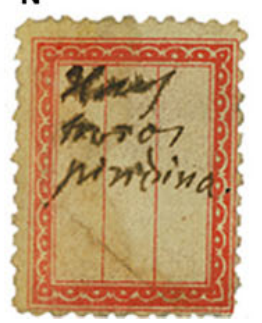

$\mathbf{J}$

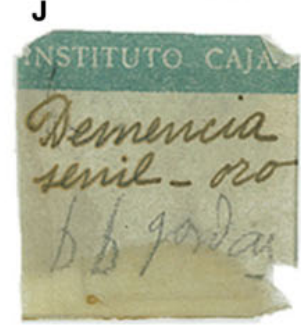

0

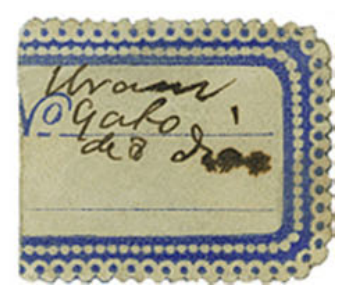

FIGURE 2 | Different labels Cajal attached to his histological preparations during his life. (A) 1877-1884, when Cajal was in Zaragoza; (B), 1884-1897, when Cajal was in Valencia; (C) between 1887-1892 when he was in Barcelona; (D-H) from 1892 to 1920, Madrid; (I-K) approximately belong to the period after 1920; (L) from 1887, when he started to study neoplasias; (M-O) labels found in many histological slides probably from when he moved to Madrid until the end of his career.

Thereafter, Cajal moved to Madrid to work in the San Carlos Hospital and the Laboratory of Biological Research until 1920 (Figures 2D-H). In 1920, the Cajal Institute was created by royal decree by King Alfonso XIII. Although the Cajal Institute was not built until 1932, its name was in use from 1920.

In addition, we also have considered the publication date of Cajal's articles in which particular histological preparations appear. For example, a preparation specific to a study of the growth cone (Figures 3A,B) must date from at least 1890, or if the histological sections show neurofibrils it will be from no before than 1903 (Figure 4). Finally, the staining/impregnation method used in the preparations was also taken into account. Thus, tissue prepared with the reduced silver nitrate method (Figure 4) could have been made in or after 1903, the year when he developed that method. In this way, the most accurate dating of the histological preparations was achieved.

\section{CLASSIFICATION OF THE HISTOLOGICAL PREPARATIONS ACCORDING TO THE BIOLOGICAL DISCIPLINE}

Some 3,003 histological preparations ${ }^{5}$ have been classified into three groups according to the biological discipline:

\section{Histology (2,254 slides, approximately 75\%);}

${ }^{5}$ We have only classified those preparations where the label indicated the subject under study on the slide. There are other histological slides which have no indication of the subject, area or staining method used on their labels and these have not yet been classified.
2. Pathological anatomy (728, approx. 24\%); and 3. Microbiology (21, approx. 1\%: Table 1).

In the Histology group, most slides corresponded to those used to study the Nervous System (1,952, 65\%), (Figures 3, 4, 6B-H, 7 and 8), whereas the rest $(302,10 \%)$ are related to other histological fields such as the structure of the muscle fibers (Figure 9A). Pathological anatomy includes preparations used to describe the diseases related to the nervous system (Figure 5), such as rabies, "general paralysis of the insane" ${ }^{\prime \prime}$, dementia praecox ${ }^{7}$ or Alzheimer's disease, as well as the studies on degeneration and regeneration in the nervous system. We have also included in this group his studies of neoplasias (Figure 10) and other diseases not directly related to the nervous system, such as Leprosy (Figure 10A). Finally, Microbiology is a very small group in which the different microbes studied by Cajal are included (Figure 11A).

The proportion of the slides in each group show the tendencies in Cajal's research. The largest number of slides are devoted to the nervous system about which Cajal wrote his main contributions. There are also a significant number of preparations dealing with Pathological Anatomy, because Cajal was the Chair of the Department of Pathology at the Universities of Barcelona and Madrid. Although

${ }^{6}$ Syndrome of madness and wakeness, and the progressive degeneration occurring in tertiary syphilis. Actually, neurosyphilis refers also to general paralysis of the insane.

${ }^{7}$ Termed coined by Kraeplin (1893) that would later be called schizophrenia (Bleuler, 1908). 

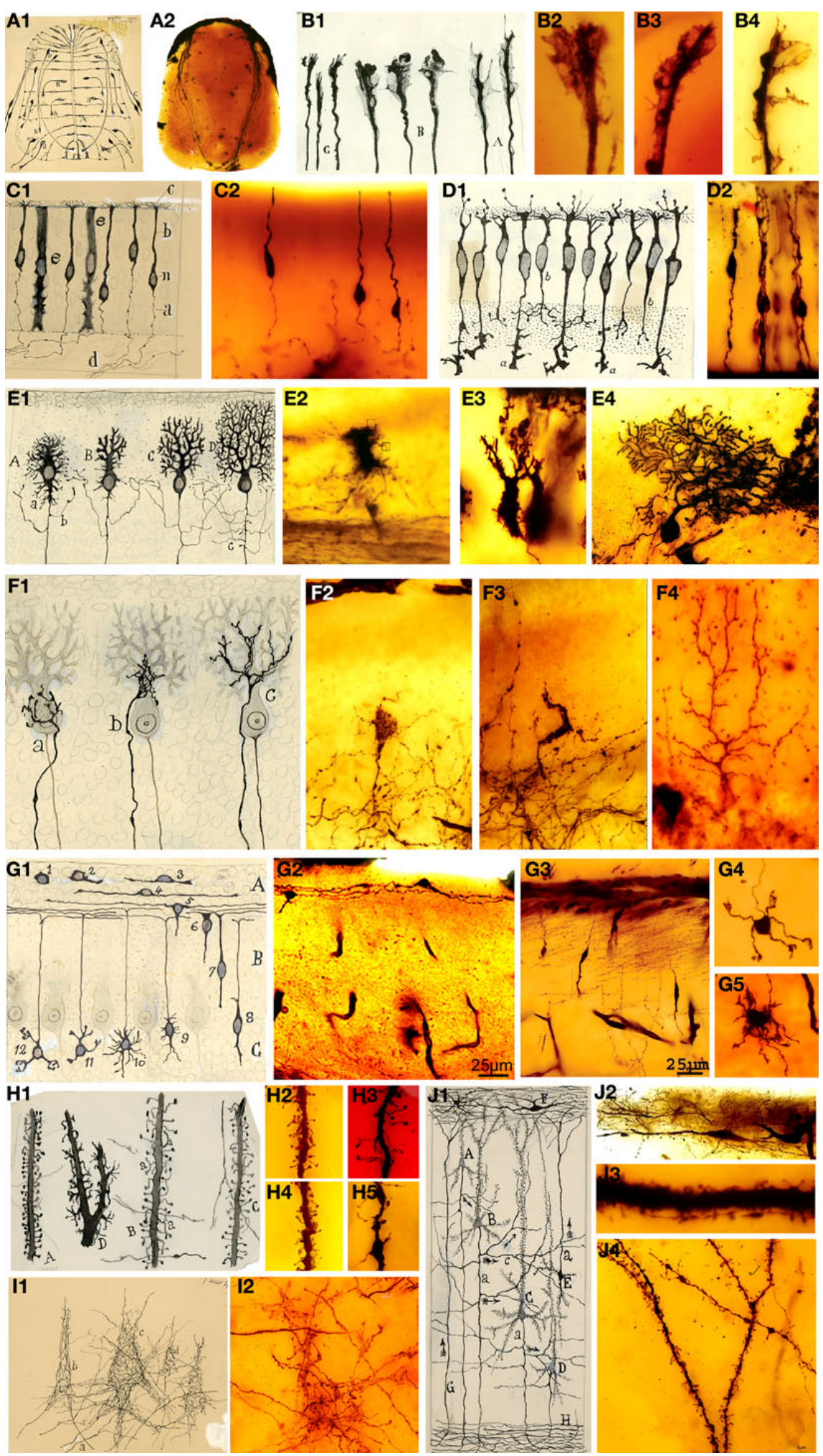

FIGURE 3 | Cajal's histological preparations and drawings showing some of his most important discoveries with the Golgi Method. (A) Chicken spinal cord; (B) 3 day-old chicken growth cones; (C) Cells from the olfactory mucosa; (D) Bipolar cells (for rods and cones) from the retina of cat; (E) Development of Purkinje cells in bird; (F) Climbing fiber (pericellular nest stage), newborn dog; (G)
Development of granule cells in the cerebellum; (H) Dendritic spines of a pyramidal cell of the frontal cortex of man (unknown age); (I) Basket formation in motor cortex of 15-day-old child; (J) Pyramidal cells (J1,A,B,C,D,E) and CajalRetzius cell (J1,F,J2) of the cerebral motor cortex of a 15-old-day child. (Drawings reproduced with the permission of the Inheritors of Santiago Ramón y Cajal (C). 

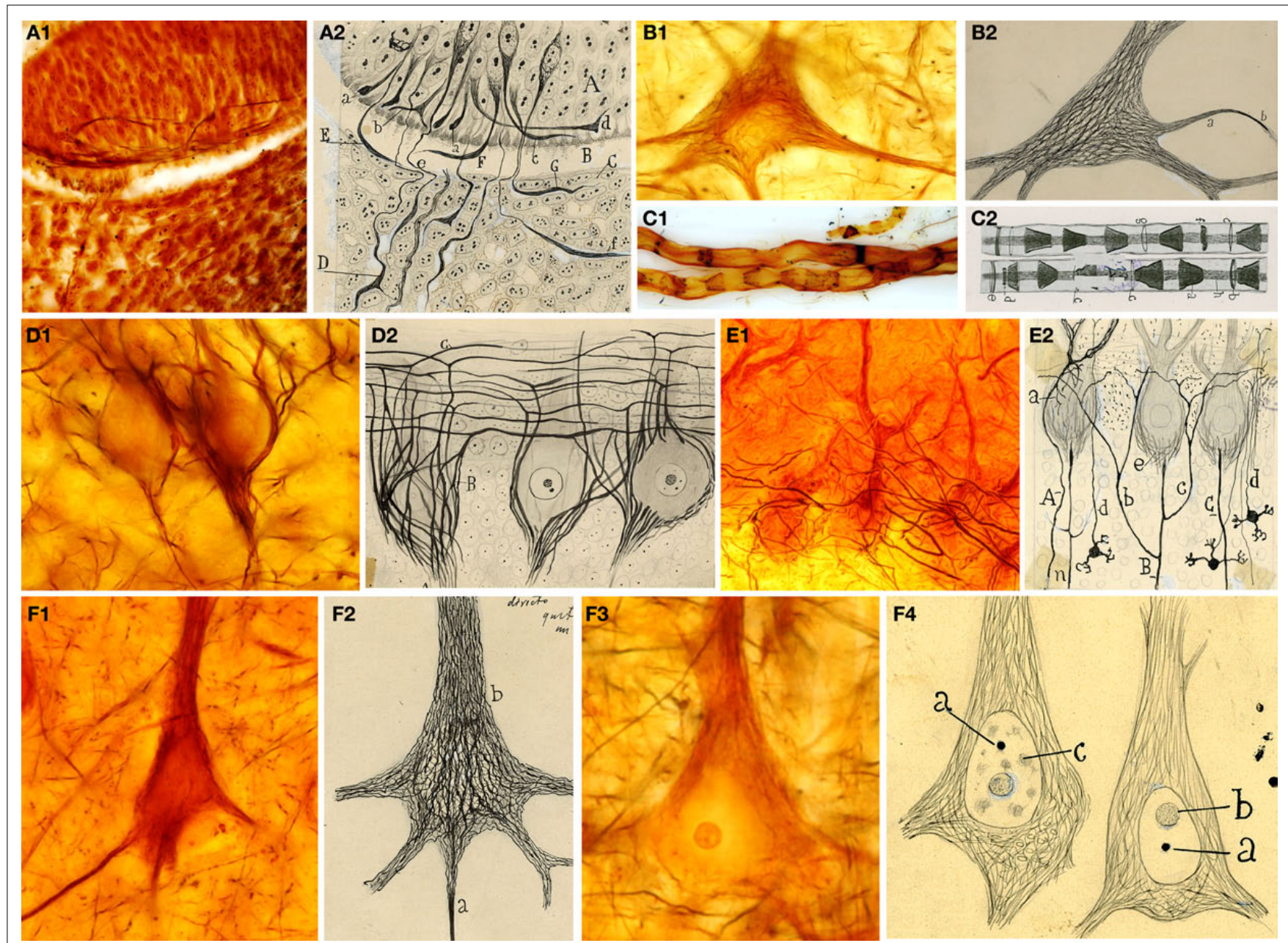

FIGURE 4 | Cajal's histological preparations and drawings showing some of his most important discoveries with the Reduced Silver Nitrate

Method. (A) Growth cones of the spinal cord of chicken embryo on the fourth day of incubation; (B) Neurofibrils in a motoneuron in a cat; (C) Schmidt-

Lantermann's clefts; (D) Basket cells arborization surrounding Purkinje cells in cerebellum; (E) Axonal plexus (E1); climbing fibers and recurrent axon collaterals of Purkinje cells (E2); (F1,F2) Neurofibrils in a pyramidal cell; (F3,F4) Nucleolus (b) and other nuclear components of the pyramidal cells: Cajal's body (a). (Drawings reproduced with the permission of the Inheritors of Santiago Ramón y Cajal (C). this aspect of Cajal's work is less well known, he did make important contributions to research on neoplasias (Figures 9B and 10: see Martínez et al., 2005). For instance, he proposed his "general doctrine of tissue composition" in which it is possible to recognize the current concept of tumor stem cells. He also studied the importance of the stroma and angiogenesis for the establishment of tumors, and he discovered the existence of plasma cells in the tumor stroma. His contributions to the comprehension of pathologies of the nervous system are especially interesting. Cajal's histological slides of Alzheimer's disease (37 slides: Figure 5C) led him to make important proposals about the pathological lesions in this disease (see Garcia-Marin et al., 2007b). Furthermore, other diseases such as dementia praecox (3 slides: Figures 5D and 12B), Neurosyphilis (130 slides: Figures 5F,G), and rabies ( 30 slides: Figure 5E) were also studied by Cajal and he defined some of the pathological lesions in these diseases. For example, the gliosis (astrogliosis and microgliosis) in neurosyphilis (Cajal, 1925) or the hypertrophy of neurofibrils in rabies (Cajal and Garcia, 1904).
The work of Cajal as a microbiologist is less well known, although during his period in Zaragoza and Valencia (1877-1887) he carried out some microbiological studies, providing experimental proof for chemical vaccination (Cajal, 1885). From all this information, we can conclude that Cajal not only focused on the Nervous System, but that he had a rich background in other areas of the biological sciences, permitting him to extrapolate knowledge from different disciplines. For instance, the chemotactic movement of leucocytes helped him to propose his neurotropic theory in the Nervous System (Cajal, 1893).

\section{CLASSIFICATION OF THE HISTOLOGICAL PREPARATIONS ACCORDING TO THE STAINING METHODS}

The staining method has been determined in 4,009 of 4,529 histological preparations ( $88 \%$ of the total: Table 2 ), a further analysis is needed to complete the classification. The majority of these histological preparations were made using the reduced silver nitrate (2,054: Figure 4) or the Golgi methods (809: Figure 3). Regarding their specificity to 
Table 1 | Classification of the histological slides according to the biological discipline.

\begin{tabular}{|c|c|c|}
\hline HISTOLOGY: 2254 & Salivary gland (13) & Spinal cord (211) \\
\hline Tissues: $\mathbf{4 6 1}$ & Esophagus (3) & Retina (173) \\
\hline Epithelial tissue: (69) & Stomach (7) & - Peripheral nervous system \\
\hline Hair (21) & Pancreas (17) & Ganglia (114) \\
\hline Nails (1) & Liver (10) & Nerves (78) \\
\hline Skin (41) & Reproductor system: (14) & Olfactive mucosa (6) \\
\hline Mammary glands: (3) & Ovary (7) & Tendinous organ (1) \\
\hline Cartilaginous and bony tissue: (6) & Urinary system: (4) & - Autonomus Nerv. Sys: (21) \\
\hline Blood: (6) & Kidney (4) & - Nerv. Syst. invertebrates: (58) \\
\hline Muscle tissue: (59) & Endocrine system: (14) & PATHOLOGICAL ANATOMY: 728 \\
\hline Nervous tissue: (315) & Pancreas (14) & - Nervous system diseases: Alzheimer, \\
\hline Golgi apparatus (29) & Spleen (3) & -Degeneration and regeneration of the \\
\hline Nissl granules (30) & Thymus (3) & Nervous System: (391) \\
\hline Growth cones (29) & Nervous system: (1464) & MICROBIOLOGY: 21 \\
\hline Dendritic spines (16) & - Central nervous syst: (1182) & Yersinia pestis: (2) \\
\hline - Glia: (150) & Cerebral cortex (367) & Mycobacterium tuberculosis: (8) \\
\hline Organs and systems: 1626 & Basal ganglia (1) & Bacillus anthracis: (1) \\
\hline Respiratory system: (20) & Hippocampus (46) & Vibrio cholerae: (2) \\
\hline Nose (5) & Olfactory bulb (51) & Bacillus unspecified: (5) \\
\hline Larynx (4) & Thalamus, hypothalamus (29) & Gonococcus: (1) \\
\hline Trachea(4) & Mesencephalon (17) & Treponema pallidum: (1) \\
\hline Lung (7) & Pons (34) & Plasmodium falciparum: (1) \\
\hline
\end{tabular}

stain the nervous system, we could classify the staining methods into two groups: (i) methods generally used to stain different components of the nervous system (90\%), such as the Golgi (Figure 3), Bielschowsky, Ehrlich (Figures 8A,B), Marchi, Nissl (Figures 6G2 and 7E2), formalin-uranium nitrate (Figures 6A-D and 7A1,C1), reduced silver nitrate (Figures 4 and 7F2), gold-sublimated chloride (Figure 7A2), silver carbonate (Figure 7B1) and ammoniacal silver oxide (Figures 7E1,F1) methods; (ii) general methods used in the histological study of other organic systems ${ }^{8}$ (10\%), like Cohnheim, Van-Gieson, Loewitt, carmine, hematoxylin and eosin (Figures 9B and 10C-F) and trichromic (Figure 10B4) stainings.

Throughout his career, Cajal introduced new staining methods that enabled him to observe different details in the organization of the nervous tissue. The methods invented by Cajal include: the trichromic method (Cajal, 1896a) for the staining of neoplasias; the reduced silver nitrate method (Cajal, 1903a) to stain neurofibrils; the formalin-uranium nitrate method (Cajal, 1912) to stain the Golgi apparatus; and gold-sublimated staining (Cajal, 1913, 1920) that specifically stains astrocytes in the white matter, as well as those in the gray matter that were very difficult to observe (see Garcia-Marin et al.,

${ }^{8}$ This is a general classification based on the common use of these staining methods, although the Golgi method can also be used to stain muscle and glandular tissue (Cajal, 1889a) or the epithelia (Cajal, 1919a). 2007a). Cajal also introduced new variants to preexisting staining methods, such as his fast variant of the Golgi method (Cajal, 1889a) that produces excellent results in embryonic tissue (Figures 3A,B), the double impregnation variant of the Golgi method for those fibers or cells that were very difficult to stain (Cajal, 1889b), or his propagation variant of Methylene blue staining (Cajal, 1896b). In addition, Cajal always tried to correlate different staining methods to be sure of the morphological characteristics of certain structures. For example, he also used correlative staining for the Golgi method such as the Weigert and Nissl stainings. Furthermore, he studied the dendritic spines with the Golgi method (Cajal, 1888) (Figure 3H) and Methylene Blue staining (Cajal, 1896b; see Garcia-Lopez et al., 2007), while he used the Golgi method and reduced silver nitrate staining to correlate the morphological changes of the dendritic arbor during development with the changes in the neurofibrillar scaffold (Cajal, 1903b).

\section{CLASSIFICATION OF THE HISTOLOGICAL SLIDES ACCORDING TO SPECIES}

Regarding the species studied by Cajal, a wide variety of invertebrates and vertebrates were included for study (Table 3$)^{9}$. We have tabulated these according to their common or scientific name and

${ }^{9}$ We have only classified those preparations in which the label indicates the animal from which the tissue was obtained. There are other histological slides that do not have any animal's name on their labels and that have not yet been classified. 

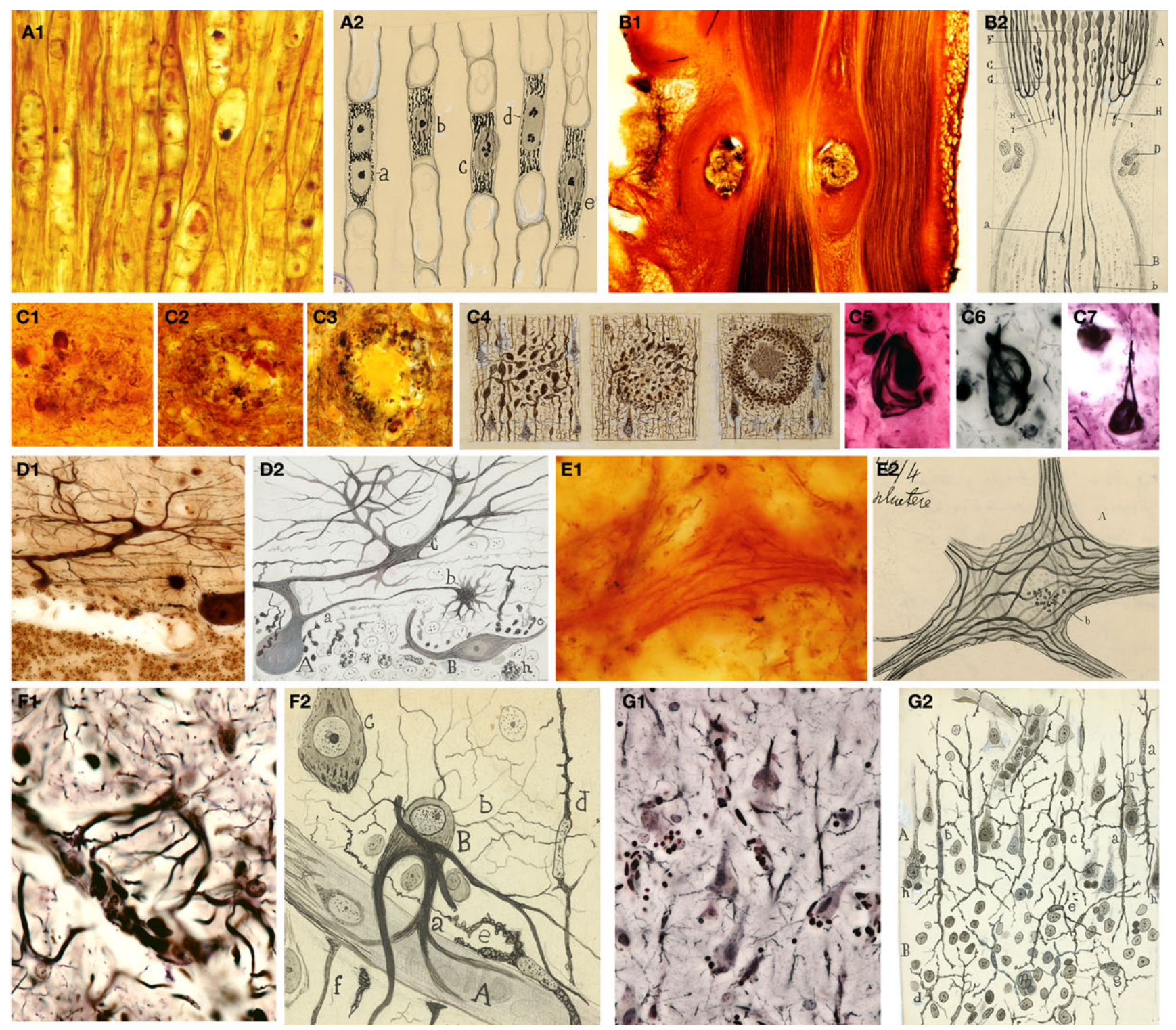

FIGURE 5 | Cajal's histological preparations and drawings showing some contributions to the pathology of the Nervous System. (A) Degeneration of nerve fibers (reduced silver nitrate); (B) Experiment of ligadura in the peripheral nervous system (reduced silver nitrate); (C) Senile plaques and neurofibrillary tangles in Alzheimer's disease (reduced silver nitrate and ammoniacal silver oxide); (D) "dementia praecox" in Purkinje cell with

their corresponding phyla. In this table, it is evident that by studying many different species, Cajal made important contributions to the field of comparative anatomy, as well as to understanding of the general organization of the nervous system. One of the reasons that Cajal studied such a variety of different animals was that he used the ontogenic method. Instead of studying the nervous system in complex adult animals, he studied it in simpler, younger animals, which meant that the tracking of a fiber from its origin to its target was shorter. In addition, as myelinization is absent or less dense in young animals and some invertebrates, their fibers could be more readily impregnated. Among the animals used by Cajal, the typical asteriform apparatus (reduced silver nitrate); (E) Neurofibrils in a motoneuron in a dog with rabies, reduced silver nitrate; (F) Giant astrocytes in a man with progressive general paralysis (ammoniacal silver oxide); (G) Rod microglia cells of a man with progressive general paralysis (ammoniacal silver oxide). (Drawings reproduced with the permission of the Inheritors of Santiago Ramón y Cajal (C). 
Table 2 | Staining methods of the histological slides.

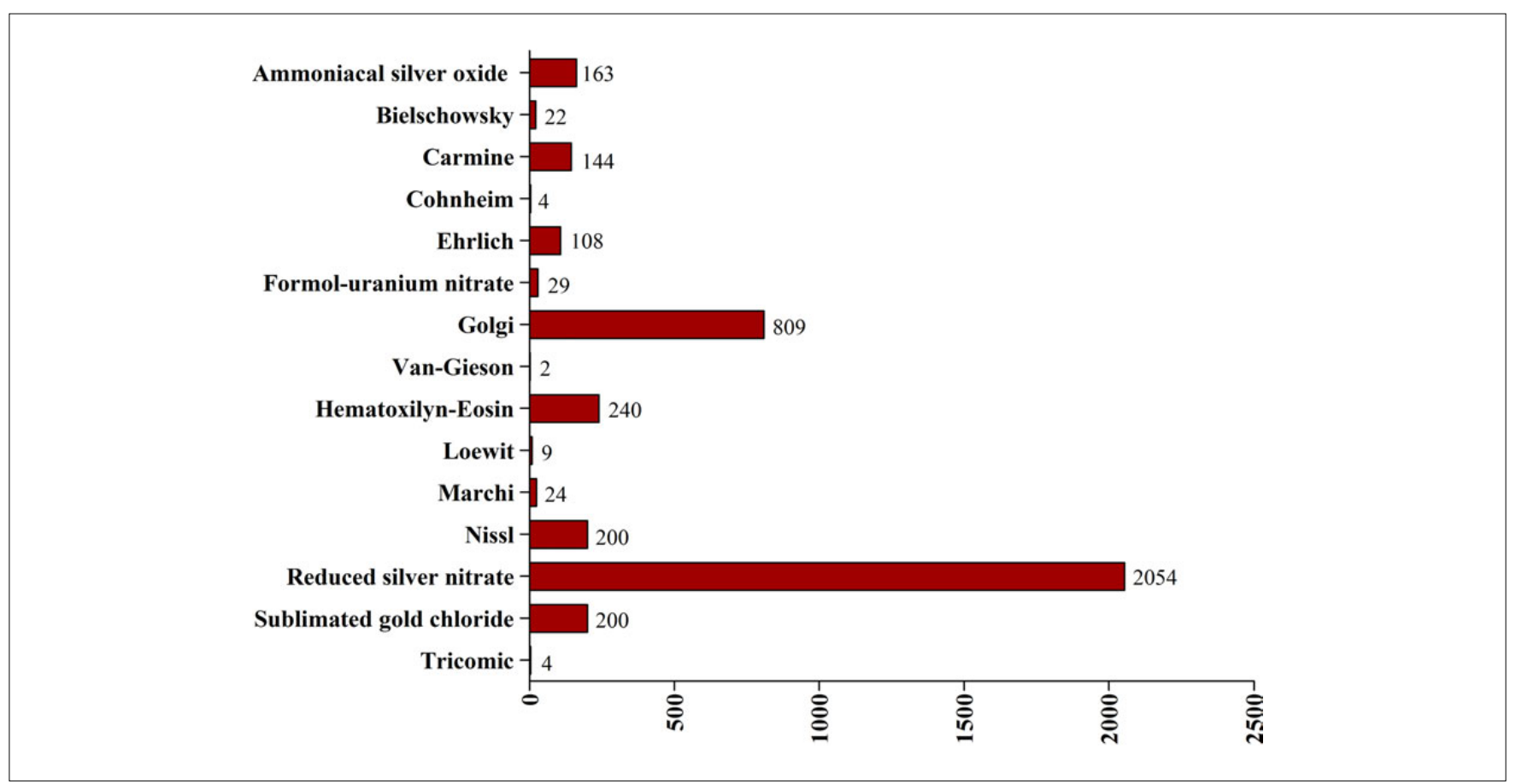

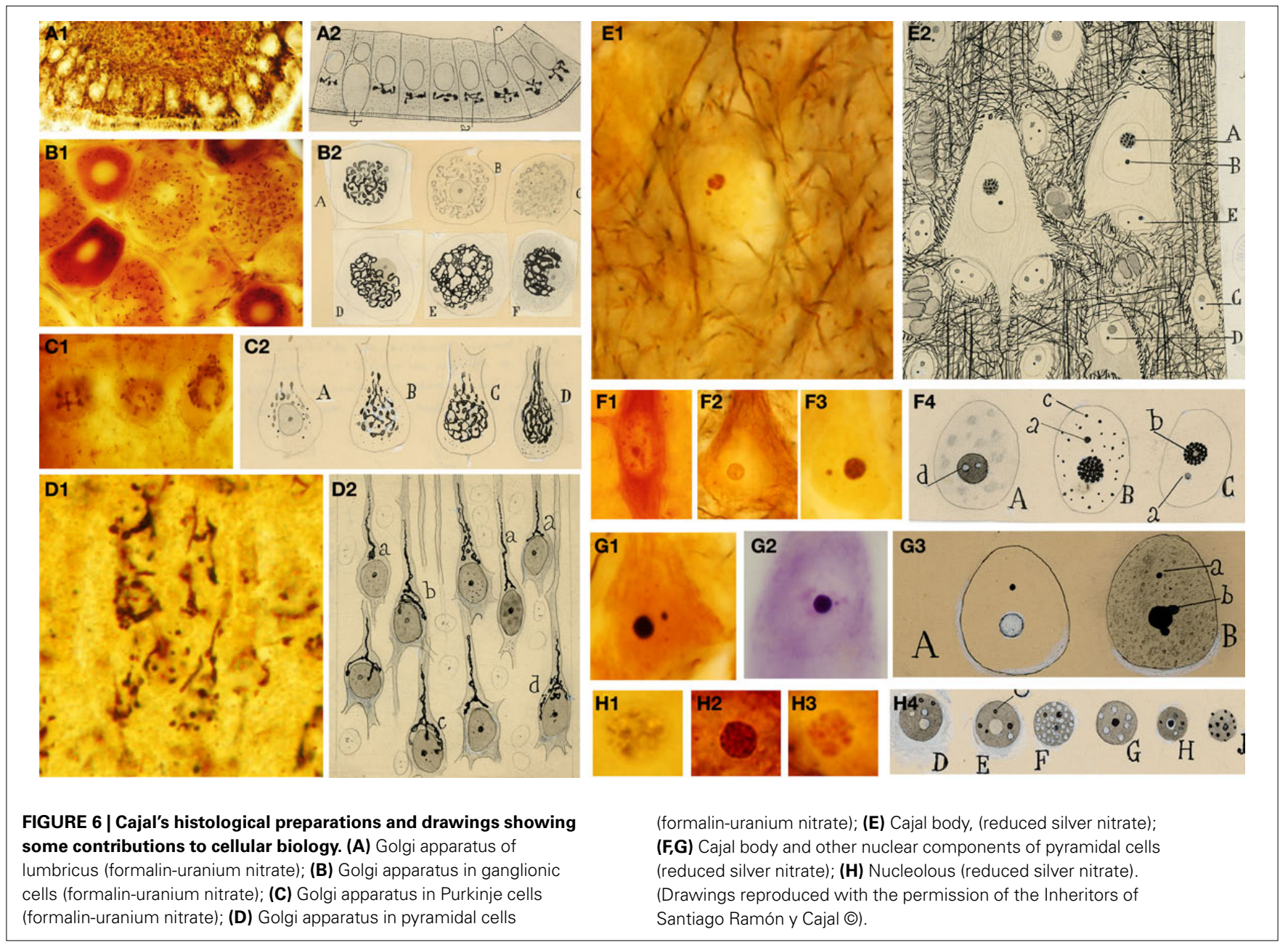



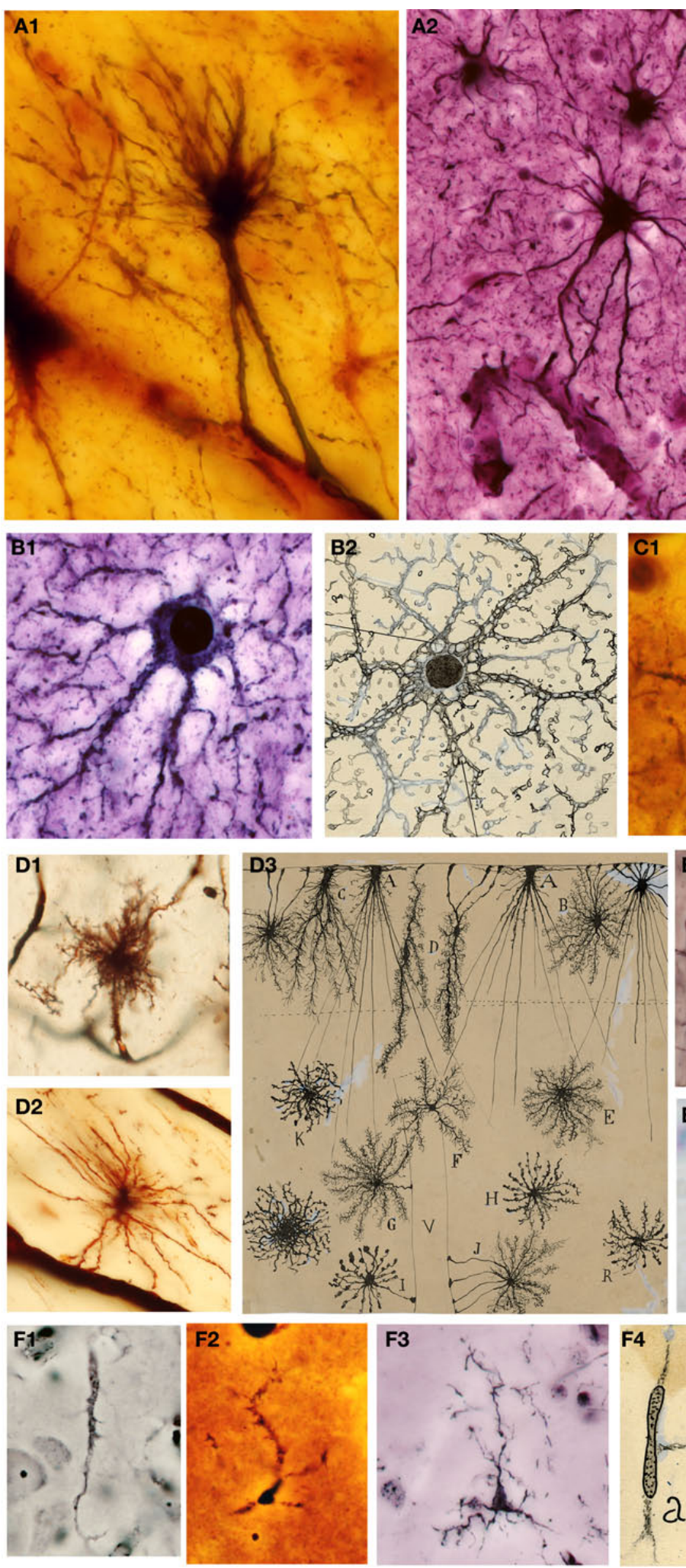

FIGURE 7 | Cajal's histological preparations and drawings showing some contributions to glial cells. (A) Fibrous astrocyte in the white matter of adult brain (formalin-uranium nitrate and gold-sublimated chloride); (B) Protoplasmic astrocyte in an adult brain (silver carbonate (del Rio) and formalin-uranium nitrate); (C) Twin astrocytes in the human hippocampus (formalin-uranium

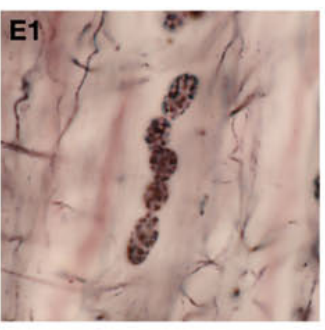

E2
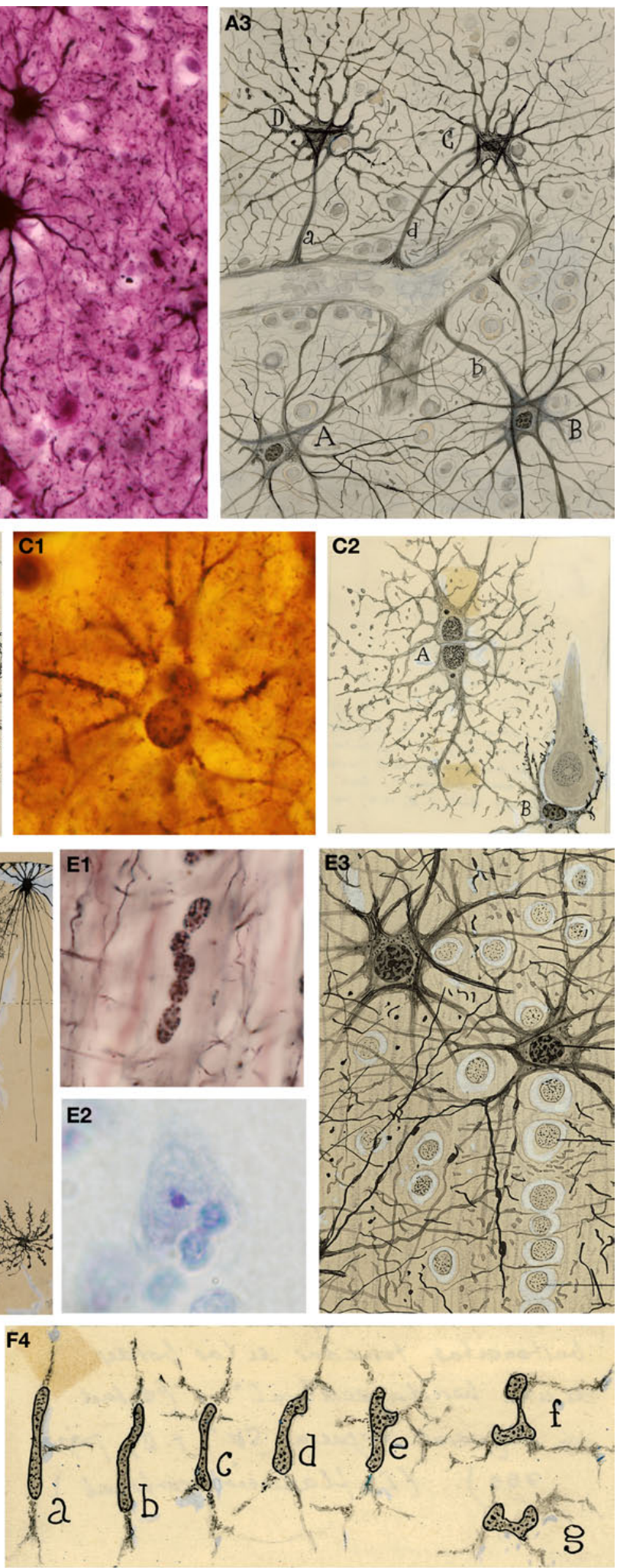

nitrate); (D) Fibrous astrocytes from the white substance of adult brain (Golgi methods); (E) Olygodendrocytes (ammoniacal silver oxide and Nissl); (F) Microglia cells (ammoniacal silver oxide, reduced silver nitrate and silver carbonate (del Rio) methods). (Drawings reproduced with the permission of the Inheritors of Santiago Ramón y Cajal @). 
Table 3 | Animals used by S. Ramón y Cajal for making his histological slides.

\begin{tabular}{|c|c|c|}
\hline INVERTEBRATES: 64 & Cephalochorda: 2 & Young pigeon: (9) \\
\hline Anelides: 11 & Amphioxus: (2) & Duck: (14) \\
\hline Leech: (7) & & Partridge: (1) \\
\hline Earthworm: (4) & VERTEBRATES: 1990 & Moorhen: (1) \\
\hline Molluscs: 16 & Fishes: 22 & Chicken: (109) \\
\hline Squid: (1) & Trout: (19) & Nightingale: (8) \\
\hline Snail: (4) & Electric ray: (3) & Magpie: (1) \\
\hline - Subf. Coleoptera: 1 & Frog: (21) & Mouse: (173) \\
\hline Hydrophilus: 1 & Tadpole: (2) & Rat: (25) \\
\hline - Subf. Crustacean: 14 & Reptiles: 29 & Guinea pig: (3) \\
\hline Asellus: (2) & Snake: (2) & Rabbit: (425) \\
\hline Lobster:(3) & Water snake: (1) & Sheep: (3) \\
\hline Bee: (6) & Birds: 195 & Ox: (18) \\
\hline Wasp: (1) & Eagle: (1) & Horse: (5) \\
\hline Cricket: (3) & Hen: (6) & Calf: (1) \\
\hline Dragonfly: (2) & Wanderer: (26) & Bull: (2) \\
\hline Fly: (6) & Sparrow: (8) & Cow: (15) \\
\hline \multirow[t]{2}{*}{ Grasshopper: (2) } & Owl: (1) & Man: (154) \\
\hline & Dove: (9) & Total: 2,054 \\
\hline
\end{tabular}

phylogenetic scale, with which he reached conclusions about the complexity of the psychic cell during evolution, the plasticity of neurons, the importance of nervous activity for the development of the dendritic trees and his cerebral gymnastics theory (Cajal, 1892, 1894, 1899-1904; reviewed in DeFelipe, 2006; Elston, 2007). In addition, Cajal also studied a number of nervous systems in different invertebrate species. For example, he studies neurofibrils in annelids (Cajal, 1904; Figure 12C), the retina and optic nerve of cephalopods (Cajal, 1917), the retina, optic centers, compound eyes and ocelli (Figure 11B) (Cajal, 1910; Cajal and Sánchez, 1915) of arthropods, and muscle fibers in the grasshopper and cricket (Cajal, 1887).

Although Cajal studied the general structure of the nervous centers in many vertebrates (Cajal, 1899-1904), he particularly focused his study of the retina and the plexus of Auerbach in amphibians (see Garcia-Lopez et al., 2009). He also studied the organization of the retina, optic nerve, optic lobe and cerebellum in different lizards and birds. Chicken and ducks were utilized in many of his studies of the spinal cord (Figures 3A and 4A) and growth cones (Cajal, 1890) (Figure 3B) (see Garcia-Marin et al., 2009).

There are also 154 histological slides made from human tissue in the Museum, which were especially important to study the organization of the cerebral cortex. In these studies, Cajal discovered the terminal baskets of the basket cells (Cajal, 1899a; Figure 3I) or the bitufted cells (double bouquet: Cajal, 1899b), which were especially abundant in humans and less so or absent in other animals (double bouquet cells have never been described in the cerebral cortex of rats or mice; see DeFelipe, 2002). He also studied the development of the nervous system in histological slides of children and foetuses, and he studied the brain of specific pathologies such as Alzheimer's disease and neurosyphilis.

For Cajal, the use of the adequate animal for a specific topic was very important:

"It is very important to choose the proper animal to obtain good results. The dimensions of the organ that is being studied, the relationships this organ establishes with other organs and surely, some unknown chemical characteristics, favour or impede the reaction, or they reduce its detail and extension. In this way, the retina is better stained in big birds and reptiles rather than in lizards, fish and mammals. The cerebral cortex of an 8-day-old rabbit is better impregnated than the cortex of rat, guinea pig, white mouse, dog, etc. of the equivalent developmental age. The spinal cord of bird embryos attracts silver chromate more constantly than the spinal cord of reptiles and mammals; the optic lobe of birds is better stained than the optic lobe of mammals"10. (Cajal and De Castro, 1933).

Furthermore, Cajal's research was very systematic, since each cell or fiber needed different impregnation times depending on the animal, the age and the staining method.

\footnotetext{
10"Es condición muy importante para los buenos resultados escoger el animal más conveniente. Las dimensiones del órgano que se estudie, las relaciones con los otros y seguramente ciertas particularidades químicas desconocidas, favorecen o estorban la reacción o le restan finura y extensión. Así la retina se tiñe mejor en los pájaros y grandes reptiles que en los batracios, los peces y mamíferos.; la corteza cerebral del conejo de 8 días imprégnase mucho mejor que la de la rata, cobaya, ratón blanco, perro etc., de edad correspondiente a la misma época evolutiva. La médula espinal de los embriones de ave atrae más constantemente el cromato argéntico que la de los embriones de reptiles y mamíferos; el lóbulo óptico de las aves se tiñe mejor que el lóbulo óptico de los mamíferos".
} 
"it is necessary to advert, that not every organ is impregnated as easily as the others. Among the most easy and constant centers to be impregnated, we find: A) Ammon's horn of 8-15 day old rabbit; 15-20 day old brain of the same animal or cat; spinal cord of 4-5 incubation day chicken"'. (Cajal and De Castro, 1933).

According to Cajal, the suitable age of the animal to stain the cerebral cortex was 8-30 days for mice, 10-20 days for rabbit and 25-30 days for gyrencephalic animals (Cajal and De Castro, 1933).

\section{GENERAL DATA OBTAINED BY CATALOGUING THE DRAWINGS}

The drawings were catalogued into different groups by determining their authorship and date of the drawings, according to the biological discipline and the species and finally, according to the technique employed.

${ }_{11}^{11}$ "Es necesario advertir, que no todos los órganos nerviosos se impregnan con igual facilidad. Entre los centros más fáciles y más constantes de teñir se encuentran: A) asta de Ammon, del conejo de 8 a 15 días; cerebro del mismo animal o del gato, de 15 a 20 días; médula espinal del embrión de pollo de 5 a 14 días de la incubación..."

\section{CLASSIFICATION OF THE DRAWINGS ACCORDING TO DATE AND AUTHORSHIP}

The majority of the scientific drawings were made by Cajal himself (1,907 of the 1,976 in total), although there are other original drawings made by Tello (37) ${ }^{12}$, Dr J. Ramón Fañanás (5), and one each from the following scientists: Domingo Sánchez, Ruiz Arcauate, Juan D. Vial, J. Sanz Ibáñez, M ${ }^{a}$ G. Amador. There are an additional 22 scientific drawings the authorship of which remains to be confirmed. To date the drawings, we chose to use the date when the drawing was first published.

\section{CLASSIFICATION OF THE DRAWINGS ACCORDING TO THE BIOLOGICAL DISCIPLINE}

By studying the scientific drawings, we can observe a highly logical correlation between the different biological disciplines studied in his histological slides and scientific drawings. The scientific drawings of Cajal are very diverse in terms of the biological discipline to which they are dedicated (Table 4 shows the number of scientific

12“Tello used professional designers to make their scientific drawings.”

Table 4 | Classification of the drawings according to the biological discipline.

\section{HISTOLOGY: 1519}

Tissues: 238

Epithelial tissue: (67)

- Skin and its appendages: (59)

- Glands: (8)

Cartilaginous and bony tissue: (34)

Blood: (22)

Muscular tissue: (28)

Nervous tissue: (87)

- Neurons: (59)

Neurofibrils: (11)

Golgi apparatus: (12)

Nucleus: (22)

Mitochondria: (3)

Dendritic spines: (2)

Growth cones: (2)

Nervous tubes: (7)

- Glia: (28)

Organs and systems: 1281

Respiratory system: (4)

Larynx (1)

Trachea(2)

Lung (1)

Digestive system: (28)

Tongue (16)

Salivary glands(2)

Esophague (2)

Stomach (2)

Liver (6)

Reproductive system: (3)

Testicle (1)

Ovary (1)

Pennis (1)

\section{Urinary system: (3)}

Kidney (3)

Endocrine system: (6)

Pancreas (6)

Circulatory/lymphoyd system: (4)

Nervous system: (1265)

- Central nervous system: (957)

Olfactory bulb (33)

Neocortex (178)

Hippocampus (54)

Callosal Body (3)

Septum (11)

Thalamus, hypothalamus, habenule,

mammillary bodies (83)

Retina (88)

Optic chiasm (5)

Mesencephalon (72)

Optic lobe(32)

Medulla and Pons(141)

Cerebellum (108)

Spinal cord (149)

- Peripheral nervous system (nerve endings and sensory organ): (129)

Ganglia (85)

Olfactory mucosa (5)

Pacini corpuscles (2)

Tendinous organ (2)

Ear (35)

- Autonomus Nerv. Sys: (16)

- Nerv. Syst. invertebrates: (163)

\section{PATHOLOGICAL ANATOMY: 303}

- Nervous system diseases, (27): Alzheimer's disease, neurosyphilis, rage, Korsakoff syndrome, dementia praecox:

- Other diseases: Goiter (1), leprosy (5), pus (3)

- Degeneration and regeneration of the Nervous System: (231)

- Neoplasias: (25)

- Golgi apparatus alterations: (11)

\section{MICROBIOLOGY: 29}

Bacilli

C. diphteriae (1)

Mycobacterium tuberculosis (4)

Yersinia pestis (3)

Bacillus anthracis (3)

Rickettsia prowazekii (3)

Klebsiella rhinoscleromatis (2)

Vibrio cholerae (1)

Clostridium tetani (1)

Brucella bovine (1)

Cocci:

Meningococcus (1)

Estreptococcus(1)

Spyrocheta:

Treponema pallidum (2)

Protozoa

(Plasmodium falciparum) (2)

Others: 4

Physiological sketches: 45

Device sketches: 10

Others: 70

Total: 1,976 

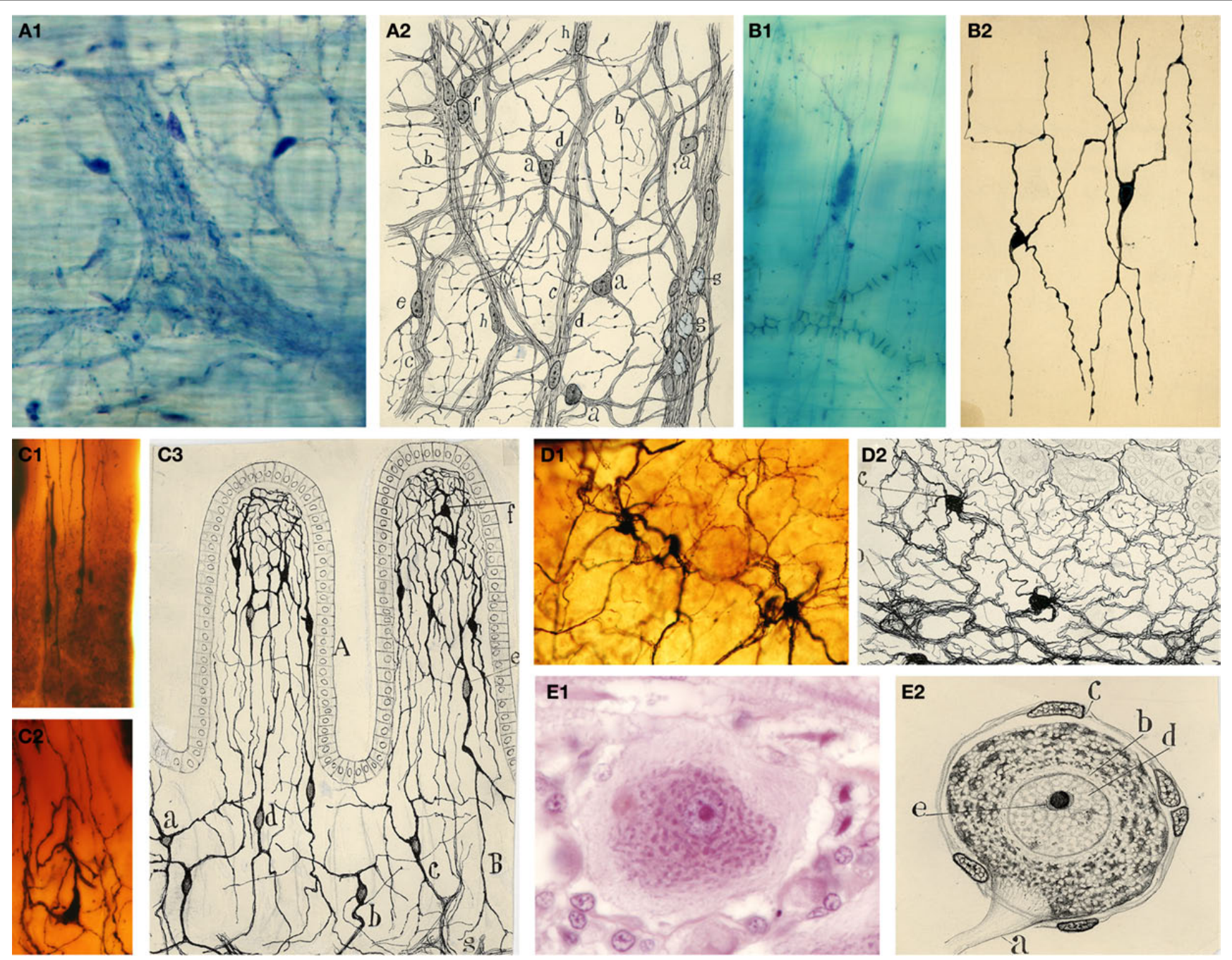

FIGURE 8 | Cajal's histological preparations and drawings showing some contributions to the peripheral nervous system. (A) Auerbach plexus and interstitial Cajal's cells of a frog (methylene blue method); (B) Interstitial Cajal's cells of the gut, (methylene blue method); (C) Intravillous plexus of the gut (Golgi method); (D) Meissner ganglion (Golgi method); (E) Ganglionic cell (Nissl) (Drawings reproduced with the permission of Inheritors of Santiago Ramón y Cajal @).

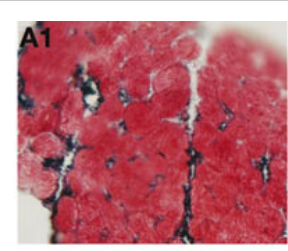

A2

A3

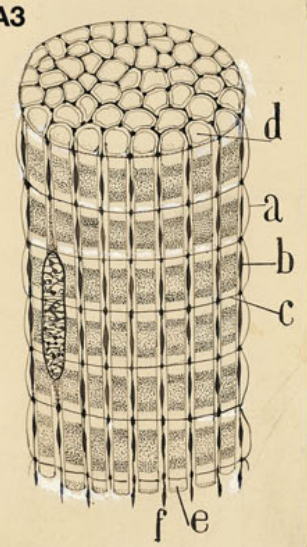

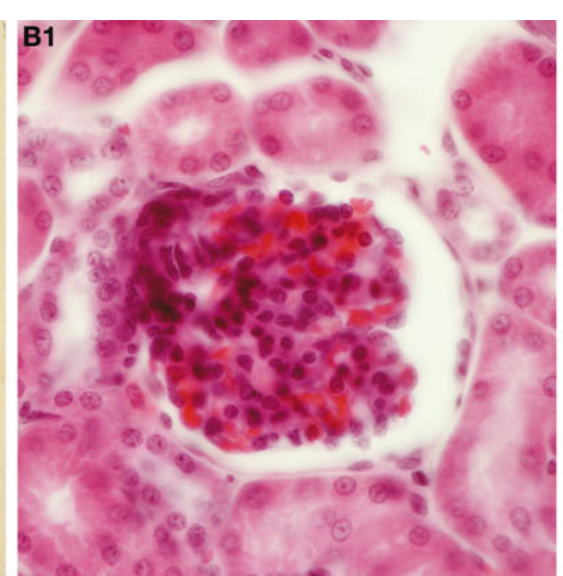

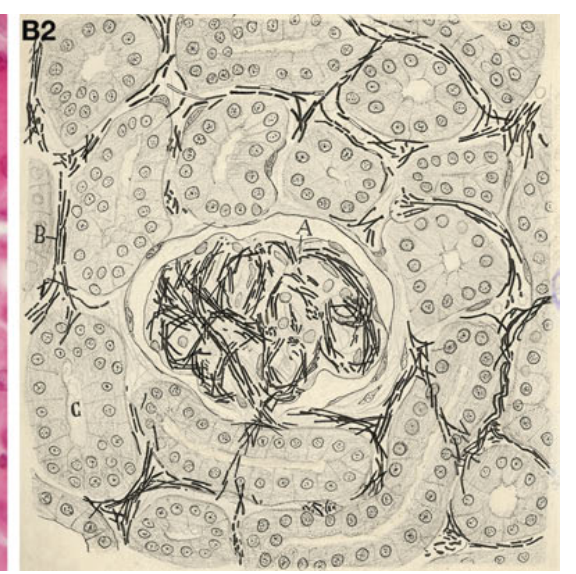

FIGURE 9 | Cajal's general histological preparations and drawings. (A) Muscle fiber, gold chloride; (B) Kidney, hematoxilyn and eosin (Drawings reproduced with the permission of Inheritors of Santiago Ramón y Cajal (C). 


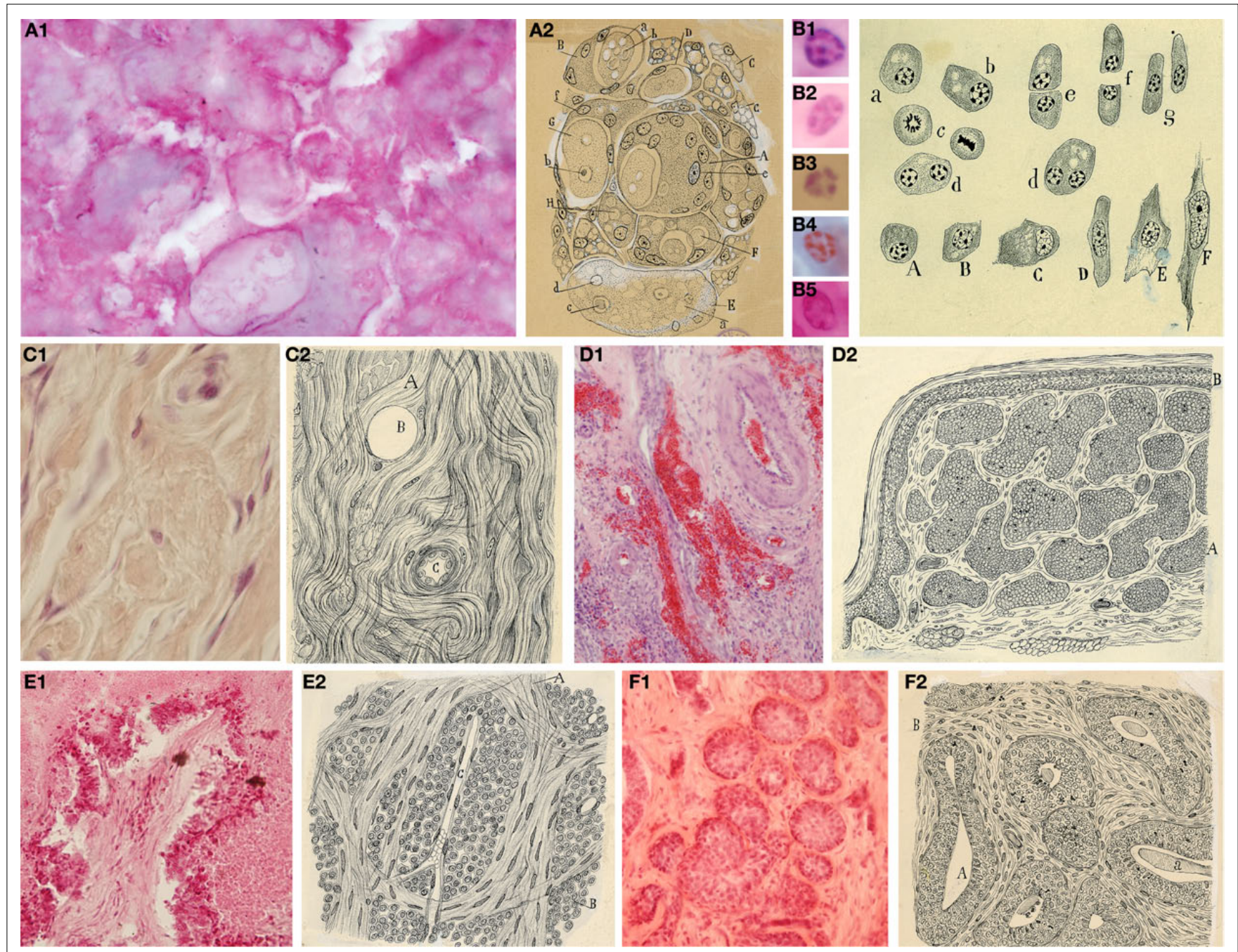

FIGURE 10 | Cajal's histological preparations and drawings about pathology. (A) Syphilitic chancre; (B) Plasma cells in connective tissue of tumor; (C) Infiltrating carcinoma of the nose; (D) Cavernous angioma of the skin; (E) Alveolar sarcoma of the nose skin; (F) Mammary gland adenocarcinoma (A1-B3,B5-F1, hematoxilyn and eosin; (B4) trichromic method). (Drawings reproduced with the permission of the Inheritors of Santiago Ramón y Cajal (C). drawings from each discipline). As in his histological slides, there are some drawings related to the histology of the tissues such as the epithelia (Figure 6A2), muscle (Figure 9A3) and the cartilagous and bony tissues. There are also some drawings showing details of the cell biology of neurons, such as those dedicated to neurofibrils (Figures 4B2,F2), the Golgi apparatus (Figures 6A2-D2) and the nucleus (Figures 6E2,F4,G3,H4), topics on which Cajal also made important contributions. Interestingly, he described the accessory body of the nucleolus in the nucleus (Figures $6 \mathrm{E}-\mathrm{G}$ : Cajal, 1903b). Other structural details of neurons, such as the dendritic spines (Figures 3H1,J1) or the growth cones (Figures 3A1, B1 and 4A2), are also the focus in four of the scientific drawings. There are also 1,233 drawings (approximately 60\%) in which Cajal illustrated the organization (Figures 3C1,D1,J1,I1) or the development of the different areas of the nervous system (Figures 3A1,E1,F1, $\mathbf{H 1 , G 1 ) . ~ I n ~ s o m e ~ o f ~ t h e s e ~ d r a w i n g s , ~ t h e ~ d i r e c t i o n ~ o f ~ t h e ~ n e r v o u s ~}$ current is indicated with arrows (Figure 3J1). It is remarkable that there are also many drawings dedicated to the study of the nervous system of invertebrates, such as those dedicated to the nervous ganglia of the lumbricus (Figure 12C2) and to the optic centers of insects and cephalopods.

As in the histological slides, there are several drawings related to the pathology of the nervous system, fundamentally rabies (Figure 5E2) and "general paralysis of the insane" (Figures 5F2,G2). Moreover, there is large group of drawings (231) that we have classified as experimental anatomopathological drawings that appeared in his book "Degeneration and Regeneration of the Nervous System" (Figures 5A2,B2; Cajal, 1913-1914). Another important group of drawings were used to illustrate his study of neoplasias (25, Figures 10C2,D2,E2,F2).

The group of scientific drawings related to microbiology is less numerous. Nonetheless it gives us an idea of the different microorganisms studied by Cajal, usually those that caused important diseases such as the cholera, diphtheria, bubonic plague, syphilis, etc. 
Finally, there are some schematic drawings that illustrate physiological principles, different pathways of the nervous system, the physiological need for the optic chiasm, sketches comparing different theories, etc. These figures are not exact copies of the histological preparation and they are intended to show illustrated general characteristics or principles of the organization of the nervous system. A special group of drawings are those explaining how technical devices function, such as the Rheinberg apparatus or Nachet's camera.

\section{CLASSIFICATION OF THE DRAWINGS ACCORDING TO THE EXPERIMENTAL ANIMALS}

We found a strong correlation when comparing the different animals that appear in the scientific drawings of Cajal with those used in the histological slides, although the proportion of drawings dedicated to the study of human nervous system is much higher (Table 5).

The drawings of cephalopoda and insects basically show the organization of the optic centers in these animals, as in the histological slides. There are also many drawings in which the optic lobe of reptiles and birds is depicted. The chicken and ducks were especially used as models in the drawings of the spinal cord (Figure 3A1). Mice, cats, rabbits and dogs were used to show the organization and development of the nervous system, also being the animals used for the studies on degeneration and regeneration of the nervous system. In addition, mice were used as the model to show the organization of the mesencephalon.

\section{CLASSIFICATION OF THE DRAWINGS ACCORDING TO THE TECHNIQUES EMPLOYED}

The materials employed by Cajal in his drawings were indian ink, pencil, watercolour, oil and white wax (stearin) for the corrections. Indian ink was used in 1,924 scientific drawings, pencil in 968, watercolour in 713 and oil in only two drawings, while white wax (stearin) was found in many of them $(1,284)$. He usually used these materials on cardboard $(1,450)$ or paper (526).

Cajal used different drawing techniques depending on the staining or impregnation method of the histological preparation he used as a model. The first part of his scientific work was largely based on the silver dichromate method (Figure 3) and with this method of impregnation, the nerve cells appeared in a dark blackish-red colour over a light yellow background. Cajal started to draw these nerve cells firstly using a pencil to draw the outline and then, indian ink to trace covering the pencil sketch. In some places, he reconsidered the pencil outline without drawing with Indian ink on top and he did not erase the pencil outline, so it can still be seen in the original drawing when observed closely. In this kind of drawing, he sometimes used watercolor to color the cells that are situated in a deeper plane, achieving a magnificent $3 \mathrm{D}$ effect. He also used watercolor when he wanted to distinguish clearly between the terminal arborization of the axon and the target cells, such as the

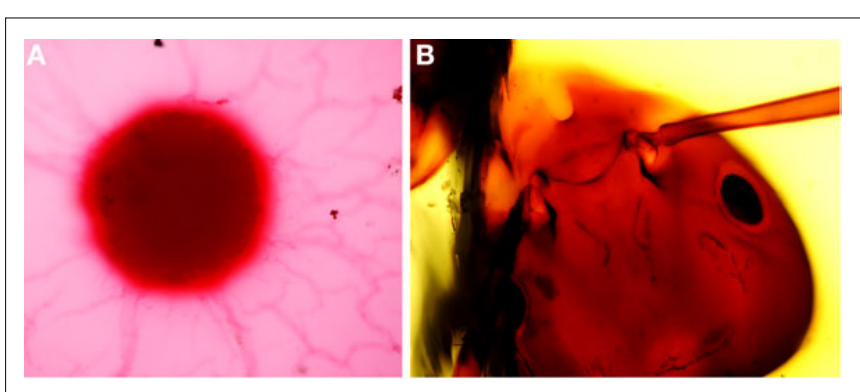

FIGURE 11 | Cajal's histological preparations on microbiology and invertebrates. (A) Syphillis, unknown method; (B) Head of an ant.

Table 5 | Animals used by Santiago Ramón y Cajal for making his scientific drawings.

\begin{tabular}{|c|c|c|}
\hline INVERTEBRATES: 161 & VERTEBRATES: 1345 & Duck: (13) \\
\hline Anelides: 15 & Fishes: 11 & Chicken: (66) \\
\hline Leech: (6) & Trout: (4) & Birds, not specified (50) \\
\hline Earthworm: (9) & Electric ray: (3) & Mammals: 1129 \\
\hline Molluscs: 23 & Barbel: (1) & Mouse: (156) \\
\hline Squid: (9) & Fishes, not specified: (3) & Rat: (8) \\
\hline Cuttlefish: (14) & Amphibians: 24 & Guinea pig: (22) \\
\hline Arthropods: 118 & Frog: (21) & Rabbit: (230) \\
\hline - Subf. Coleoptera: 1 & Tadpole: 2 & Sheep: (1) \\
\hline Beetle (1) & Toad: (1) & Cat: (224) \\
\hline - Subf. Insects: 117 & Reptiles: $\mathbf{4 0}$ & Dog: (95) \\
\hline Bee: $(23)$ & Chameleons: (12) & Pig: (1) \\
\hline Dragonfly: (16) & Small lizard: (2) & Calf: (1) \\
\hline Fly: (25) & Lizard: (10) & Ass(1) \\
\hline Grasshopper: (2) & Iguana (2) & $O x:(3)$ \\
\hline Butterfly (1) & Reptiles, not specified: (14) & Horse: (1) \\
\hline Others, not specified: 27 & Birds: 141 & Man: (286) \\
\hline Horse Fly: (23) & Sparrow: (7) & GENERAL GROUP: 440 \\
\hline Cephalochorda: 5 & Greenfinch: (1) & (Mammals, vertebrates, general sketches, etc) \\
\hline \multirow[t]{2}{*}{ Amphioxus: 5} & Dove: (3) & Microbes: 30 \\
\hline & Young pigeon: (1) & Total: 1,976 \\
\hline
\end{tabular}



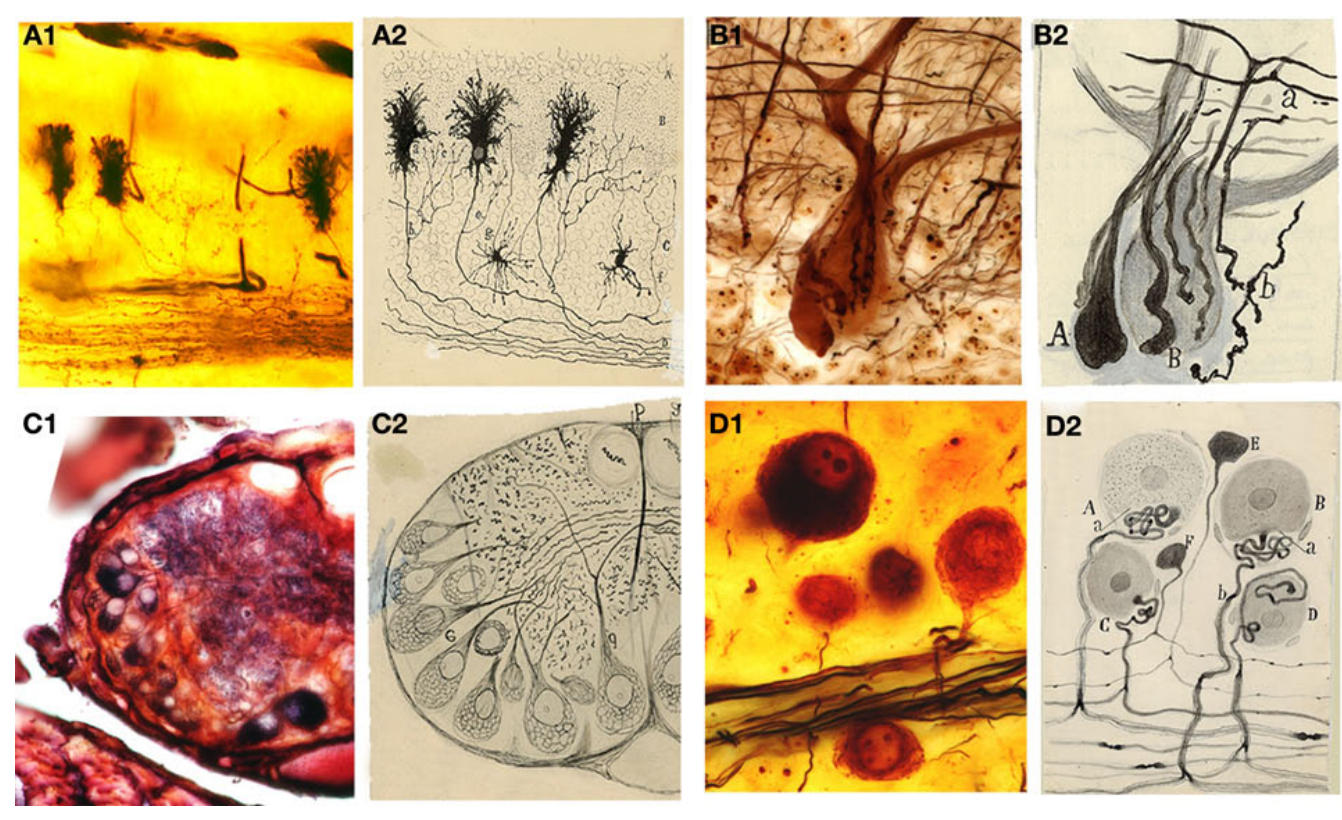

FIGURE 12 | Correlation between the histological slides and the drawings. (A1,A2) Embryonic Purkinje cell from newborn dog, Golgi method; (B1,B2) Purkinje cell of a woman with dementia praecox,

reduced silver nitrate method; $(\mathbf{C} 1, \mathbf{C 2})$ Motor neurons of a worm, reduced silver nitrate with gold toning; (D1,D2) Ganglionic cells of the trigeminal nucleus of the mouse, reduced silver nitrate method (Drawings reproduced with the permission of the Inheritors of Santiago Ramón y Cajal ()). drawings of the Purkinje cells and of the climbing or basket fibers. In this case the Purkinje cells were colored with a gray watercolor while the climbing fibers or basket fibers were colored with black indian ink (Figures 3F1,G1).

In 1903, Ramón y Cajal invented the reduced silver nitrate method, with which it was possible to study the interior of nerve cells. He changed his drawing technique to more faithfully reflect what he saw in the histological preparations. At that time, in addition to pencil and Indian ink, he used watercolors or aquarelle with grey tones to color the background (Figures 4A2,D2,E2). In the case of the formalin-uranium nitrate method (Cajal, 1912), he also used a similar approach (Figures 6A2-D2). He usually drew the outline of the cells with a pencil and then filled the interior of the cell with a graphite pencil or with gray or sepia watercolors, highlighting the Golgi apparatus with black indian ink. Cajal used a similar procedure for the histological preparations made with another method that he invented in 1913: the gold-sublimated method. In this case, besides pencil, Indian ink and grey watercolours (Figure 7A3), he also used colored aquarelle. Indeed, Cajal used color in some drawings of the calyces of Held, although in this case he used oils. Furthermore, Cajal used color when printing his histological drawings for two reasons: firstly, so that the color of the nerve cell or the background of the drawing approximated to the color the preparation; and secondly to distinguish between different nerve cells or different parts of the same nerve cell. In this context, it is interesting to highlight that the size of the original drawings is always bigger than the published size, so that the details of the drawing can be better observed. Finally, the drawings of neoplasias were made with indian ink and graphite to achieve the different textures.

\section{CONCLUSION}

The study of both the histological slides and drawings of Cajal reveals the extent of his scientific pursuits. The clarity and beauty of Cajal's histological preparations are even today aweinspiring. His faithful reproduction in his illustrations of what can be viewed in these original preparations reveals careful and attention to detail (Figure 12).

Some critics have suggested that Cajal took great artistic license in his scientific drawing. This criticism is not new, it was intimated by some of Cajal's contempories. Henschen, for example, critiziced Cajal's drawings for being too sketchy (Cajal, 1921; see also DeFelipe and Jones, 1992). However, Cajal disagreed and stated that the only liberty he took while preparing his drawings was to group cells from various serial sections (Cajal, 1921). In several figure legends (Cajal and Sánchez, 1915), Cajal clarified that the drawings had been made by grouping cells from different histological sections. Furthermore, Cajal also included a drawing based on both the reduced silver nitrate and the Golgi method (Cajal and Sánchez, 1915).

The use of the camera lucida or the drawing tube by Cajal is clear from reading his scientific work (Cajal, 1889c, 1891a,b, 1893; see also DeFelipe and Jones, 1992). However, some colleagues who saw him drawing said that he drew by looking at the histological preparation through the microscope and drawing on a piece of paper on his right-hand side, where the exact reproduction of the nerve cells of the preparation appeared without using the camera lucida (De La Villa, 1952). According to DeFelipe and Jones (1992), it is possible that Cajal first used the camera lucida to outline the profiles and the relationships of the nerve cells, and that he later filled in the details by hand, especially in large regions of brain that could not readily be retained in a single field of view. However, where he could obtain a complete 
field of view, such as in the thin non-mammalian cortex, or when he wanted to draw some details at high magnification, Cajal might have resorted to freehand drawing. As Cajal himself stated in 1889:

"The camera lucida, even when one is accustumed to its use through much practise, is only useful to fix the contour of the principal objects: any labour of detail must be done without the aid of that instrument, which has, in addition, the inconvenience of dazzling the delicate details....Reproduction by freehand drawing is the best procedure when one has some habit and liking for artistic painting". (Cajal, 1889c; taken from DeFelipe and Jones, 1992).

\section{REFERENCES}

Bleuler,E.(1908).DiePrognosederDementia praecox (Schizophreniegruppe). Allg. Z. Psychiatr. psychisch gerichtl. Med. 65, 436-464.

Cajal, S. (1885). Estudios sobre el microbio vírgula del cólera y las inoculaciones profilácticas. Zaragoza: Tipografía del Hospicio Provincial.

Cajal, S. (1887). Notas de laboratorio. III. Músculos de las patas de los insectos. Bol. Med. Valenciano. 20, 193-202.

Cajal, S. (1888). Estructura de los centros nerviosos de las aves. Rev. Trim. Histol. Norm. Patol. 1, 1-10.

Cajal, S. (1889a). Nuevas aplicaciones del método de coloración de Golgi. Gac. Méd. Cat. 12, 1-8.

Cajal, S. (1889b). Nota preventiva sobre la estructura de la médula embrionaria. Gac. Méd. Cat. 12, 132, 174.

Cajal, S. (1889c). Manual de Histología Normal y Técnica Micrográfica. Valencia, Librería de Pascual Aguilar.

Cajal, S. (1890). Sobre la aparición de las expansiones celulares en la médula embrionaria. Gac. Sanit. Barc. 2, 413-419.

Cajal, S. (1891a). Sur la structure de l'écorce cérébrale de quelques mammifères. Cellule 7, 125-176.

Cajal, S. (1891b). Sur la fine structure du lobe optique des oiseaux et sur l'origine réelle des nerfs optiques. J. Int. Anat. Physiol. 7, 1-30.

Cajal, S. (1892). El nuevo concepto de la histología de los centros nerviosos. Rev. Cienc. Méd. Barcelona 18, 361376, 457-476, 505-520, 529-541.

Cajal, S. (1893). La rétine des vertébrés. Cellule 9, 121-255.

Cajal, S. (1894). Consideraciones generales sobre la morfología de la célula nerviosa. Vet. Esp. 37, 257-260, 273 275, 289-291.

Cajal, S. (1896a). Método de coloración de las neoplasias. Rev. Cienc. Méd. Barc. 10 Marz, 2-8.

Cajal,S. (1896b). Les épines collatérales des cellules du cerveau colorées au bleu de méthylène. Rev. Trim. Microg. 1, 5-19.

Cajal, S. (1899a). Estudios sobre la corteza cerebral humana I: corteza visual. Rev. Trim. Micrográf Madr. 4, 1-63.

Cajal, S. (1899b). Apuntes para el estudio estructural de la corteza visual del cerebro humano. Rev. Ibero-Americana Cienc. Méd. 1, 14.

Cajal, S. (1899-1904). Textura del Sistema Nervioso del Hombre y de los Vertebrados. 2 vols. Madrid: Imprenta y Librería de Nicolás Moya.

Cajal, S. (1903a). Sobre un sencillo proceder de impregnación de las fibrillas interiores del protoplasma nervioso. Arch. latinos Med. Biol. 1, 1-8.

Cajal, S. (1903b). Un sencillo método de coloración del retículo protoplásmico y sus efectos en los diversos centros nerviosos de vertebrados e invertebrados. Trab. Lab. Inv. Biol. Univ. Madr. 2, 129-221.

Cajal, S. (1904). Neuroglie et neurofibrilles du lumbricus. Trab. Lab. Inv. Bio. 3, 301-310.

Cajal, S. (1910). Nota sobre la retina de los múscidos. Bol. Soc. Esp. Hist. Nat. 10, 92-95.

Cajal, S. (1912). Fórmula de fijación para la demostración fácil del aparato reticular de Golgi. Bol. Soc. Geogr. Biol. 1, 263-269.

Cajal, S. (1913). Un nuevo proceder para la impregnación de la neuroglía. Bol. Soc. Esp. Bio. 2, 104-108.

Cajal, S. (1913-1914). Estudios sobre la degeneracion y regeneración del sistema nervioso, 2 vols. Madrid: Imprenta de Hijos de Nicolás Moya.

Cajal, S. (1917). Contribución al conocimiento de la retina y centros ópticos de los cefalópodos. Trab. Lab. Inv. Bio. 15, 1-82.

Cajal, S. (1919). Acción neurotrópica de los epitelios (algunos detalles sobre el mecanismo genético de las ramificaciones nerviosas intraepiteliales, sensitivas y sensoriales). Trab. Lab. Inv. Bio. $17,181-228$.

Cajal, S. (1920). Una modificación del método de Bielschowshy para la impregnación de la neuroglia común y mesoglía y algunos consejos acerca de la técnica del oro-sublimado. Trab. Lab. Inv. Bio. 18, 129-141.

\section{ACKNOWLEDGMENTS}

We thank to the inheritors of the Santiago Ramón y Cajal estate $\odot$. We would also like to acknowledge Javier DeFelipe for his comments and suggestions and specially to express our gratitude to Guy Elston for his editorial assistance. This work was made posible thanks to the conservation-restoration work of Pilar Sedano Espín, Eugenia Gimeno Pascual, Juan Antonio Sáez Décano and Sonia Tortajada Hernando, and the efforts of the former director of the Cajal Institute, Ricardo Martínez Murillo. Pablo Garcia-Lopez is supported by the Caixa Galicia Foundation. The authors were supported by the Spanish Ministry of Science and Education (BFI 2001-0705).

Cajal, S. (1921). Textura de la corteza visual del gato. Trab. Lab. Inv. Bio. 19, 113-146.

Cajal, S. (1925). Contribution à la connaisance de la néuroglie cérébrale et cérébélleuse dans la pralysie générale progressive. Trav. Lab. Rech. Biol. Univ. Madr. 23, 157-216.

Cajal, S., and De Castro, F. (1933). Elementos de técnica micrográfica del sistema nervioso. Madrid, Tipografía Artística.

Cajal,S., and Garcia, D. (1904). Variaciones del retículo de las células nerviosas en la rabia. Trab. Lab. Inv. Biol. Univ. Madrid 3, 213-216, 322.

Cajal, S., and Sánchez, D. (1915). Contribución al conocimiento de los centros nerviosos de los insectos. Trab. Lab. Inv. Biol. 13, 1-68.

DeFelipe,J.(2002a). Sesquicentenary of the birthday of Santiago Ramón y Cajal, the father of modern neuroscience. Trends Neurosci. 25, 481-484.

DeFelipe, J. (2002b). Cortical interneurons: from Cajal to 2001. Prog. Brain Res. 136, 215-238.

DeFelipe, J., and Jones, E. G. (1992) Santiago Ramón y Cajal and methods in neurohistology. Trends Neurosci. 15 237-246.

DeFelipe, J. (2006). Brain plasticity and mental processes: Cajal again. Nat. Rev. Neurosci. 7, 811-817.

De La Villa, J. (1952). Primer Centenario del Nacimiento del Excmo Don Santiago Ramón y Cajal. Madrid, Instituto de Espafia. pp. 19-25.

Elston, G. N. (2007). Specializations in pyramidal cell structure during primate evolution. In Evolution of Nervous Systems, J. H. Kaas and T. M. Preuss, eds (Oxford, Academic Press), pp 191-242.

Garcia-Lopez, P., Freire, M., and GarciaMarin, V. (2007). The discovery of dendritic spines by Cajal in 1888 and its relevance in the present neuroscience. Prog. Neurobiol. 83, 110-130.

Garcia-Lopez, P., Freire, M., and GarciaMarin, V. (2009). Updating old ideas and recent advances regarding the Interstitial Cells of Cajal. Brain Res. Rev. 61, 154-169.
Garcia-Marin, V., Garcia Lopez, P., and Freire, M. (2007a). Cajal's contribution to Glia research. Trends Neurosci. 30, 479-487.

Garcia-Marin, V., Garcia-Lopez, P., and Freire, M. (2007b). Cajal's contributions to the study of Alzheimer's disease. J. Alzheimers Dis. 12, 161-174.

Garcia-Marin, V., García-López, P., and Freire, M. (2009). The growth cone as seen through Cajal's original histological preparations and publications. J. Hist. Neurosci. 18, 197-210.

Kraeplin, E. (1893). Psychiatrie: Ein Lehrbuch fur Studierende und Ärtze. 4th Edn. Leipzig, A. Abel.

Martínez, A., Marín, V. G., Junquera, S. R., Martínez-Murillo, R., and Freire, M. (2005). The contributions of Santiago Ramón y Cajal to cancer research - 100 years on. Nat. Rev. Cancer 5, 904-909.

Sedano Espín, P., Gimeno Pascual, E., Saéz Dégano, J. A., and Tortajada Hernando, S. (2003). Conservationrestoration project of the funds of the Cajal Museum. In Ciencia y Arte, S. Cajal, ed. (Madrid, VA, Impresores), pp. 317-325.

Conflict of Interest Statement: The authors declare that the research was conducted in the absence of any commercial or financial relationships that should be construed as a potential conflict of interest.

Received: 03 November 2009; paper pending published: 08 December 2009; accepted: 05 February 2010; published online: 10 March 2010.

Citation: Garcia-Lopez P, Garcia-Marin V and Freire M (2010) The histological slides and drawings of Cajal. Front. Neuroanat. 4:9. doi: 10.3389/neuro.05.009.2010 Copyright (c) 2010 Garcia-Lopez, GarciaMarin and Freire. This is an open-access article subject to an exclusive license agreement between the authors and the Frontiers Research Foundation, which permits unrestricted use, distribution, and reproduction in any medium, provided the original authors and source are credited. 